Techniques \& Culture

Revue semestrielle d'anthropologie des techniques

$1 \mid 1983$

Actes de la table ronde "Technologie culturelle"

\title{
Une nouvelle revue
}

\section{Robert Cresswell}

\section{OpenEdition}

Journals

Édition électronique

URL : https://journals.openedition.org/tc/1035

DOI : $10.4000 /$ tc. 1035

ISSN : 1952-420X

Éditeur

Éditions de l'EHESS

Édition imprimée

Date de publication : 1 juin 1983

ISSN : 0248-6016

Référence électronique

Robert Cresswell, «Une nouvelle revue », Techniques \& Culture [En ligne], 1 | 1983, mis en ligne le 26 janvier 2006, consulté le 29 septembre 2022. URL : http://journals.openedition.org/tc/1035 ; DOI : https://doi.org/10.4000/tc.1035

Ce document a été généré automatiquement le 29 septembre 2022

Tous droits réservés 


\section{Une nouvelle revue}

Robert Cresswell 